Barger and I became intimate colleagues for a second period, starting in July, 1914, when we joined the staff of the National Institute for Medical Research, then newly projected by the Medical Research Committee. The outbreak of war a month later deferred all normal plans, sent us into temporary quarters, and absorbed our activities in various urgent and largely separate problems. On some of these Barger did work of the highest national importance, which he would have wished to remain unrecognized. Our direct collaboration came to an end with Barger's appointment in 1919 to the chair of chemistry in relation to medicine, then founded in Edinburgh. Circumstances prevented the full realization of the scheme, which was to have put Barger in charge of the chemical aspects of teaching and research in all the medical sciences; but he retained the chair for eighteen years, and made his department an important centre of research in chemistry, often with a medical or biological outlook, to which workers came from most parts of the world.

Of achievements by those who had been Barger's pupils and collaborators in this period, mention may be made of Harington's work on the structure and synthesis of thyroxine, of which the concluding stage was published jointly with Barger; of Stedman's work on the structure of physostigmine, on artificial analogues of that alkaloid, and on the enzyme, cholinesterase, by depressing the function of which physostigmine and its allies produce their physiological effects; and of the work of Todd and his collaborators, on the structure and the synthesis of the vitamin $B_{1}$ (aneurine).

Barger, by himself, and with various collaborators from a number of countries, carried on, in the same period, a series of fundamental researches on the structure of certain alkaloids-carpaine, galegine, calycanthine and others-and synthesized the amino acid methionine. Though his interests in biology and medicine, and his contacts with workers in those fields, were wide and numerous, he always regarded. himself as a chemist, and was especially gratified by recognitions of the importance of his work for chemistry as such, as by the Longstaff Medal of the Chemical Society in 1936, and by the Davy Medal of the Royal Society, awarded less than two months before his death. His position among leading British chemists had been fitly recognized by his appointment, in 1937, to the Regius professorship of chemistry in the University of Glasgow ; but he has not lived to show what he would have made of this wider opportunity.

Apart from the numerous scientific papers published in his own name, and by pupils whom he guided and inspired, Barger published two important monographs, both dealing with interests which he acquired during our early association, and later extended. The smaller of these dealt with "The Simpler Natural Bases"; the larger and later one, based on the Dohme Lectures which he gave in Baltimore in 1928, and dealing with "Ergot and Ergotism", is a masterly piece of work, embodying much patient and scholarly historical research, and showing an unrivalled scientific grasp of the problems presented by a many-sided and fascinating subject.

Barger received many degrees from foreign universities, and was member of a number of foreign academies; but these honours do not in any way indicate the degree to which he became a truly international figure in science. His acquisition of several languages in boyhood made it easy for him to learn others, and he continued throughout life to perfect his command of those he had, at every opportunity of practice, and to seize every excuse, whether of holiday or congress, to add another to his equipment. He had a mind avid for new information and experience, and travelled often and widely, making friends in all countries. He was eager to become familiar not only with the languages, but also with the historical backgrounds and habits of thought of other peoples, and was constantly active to promote international understanding and good will. He gave and received staunch friendship, but, widely beyond the circle of those who enjoyed his intimate confidence, his loss will be mourned in many countries as that of a great figure in science, and of a generous and understanding colleague. There will be widespread sympathy with his widow, his two sons and his daughter, in their tragically sudden bereavement.

H. H. DALE.

\section{Prof. Ferdinand Hueppe}

WE regret to announce the death in Dresden at the age of eighty-six years of Geheimrat Ferdinand Hueppe, honorary senator of the Technical School of Dresden, who was not only one of the founders of modern bacteriology but also an eminent authority on public health, biology and the medical aspects of athletics.

Hueppe was born on August 24, 1852, at Heddesdorf near Neuwied on the Rhine. He qualified in Berlin in 1876 with a thesis on ovarian and abdominal pregnancy, and for the next nine years served as a medical officer in the army, during which period he paid special attention to systematic physical exercise. In 1885 he left the army and founded a Department of Hygiene and Bacteriology in the Chemical Institute of Fresenius at Wiesbaden. In 1889 , he was made professor of hygiene in the German University at Prague and held this appointment until 1912, when he settled in Dresden. In 1903 he delivered the three Harben lectures in London before the Royal Institute of Public Health on the etiology of infectious diseases, hygiene and serum, and tuberculosis respectively.

Hueppe was a prolific writer. In addition to a work on the methods of bacteriological research, and another on the forms of bacteria, he wrote on milk, water, typhoid fever, cholera, alcoholism, vegetarianism, and social and racial hygiene. J. D. R.

We regret to announce the following deaths:

Dr. F. P. Burt, M.B.E., reader in stoichiochemistry in the University of Manchester.

Prof. A. W. Porter, F.R.S., emeritus professor of physics in the University of London, on January 11, aged seventy-five years. 